\title{
Značajke razvoja javne telefonije u Hrvatskoj od 1990. do 1998. godine*
}

\author{
GORAN RAJIČ \\ Tehnički muzej Nikola Tesla \\ Zagreb, Hrvatska \\ goran.rajich@gmail.com
}

Tema članka je razvoj javne nepokretne i pokretne telefonije u Hrvatskoj pod okriljem novoosnovane nacionalne javne poštansko-telekomunikacijske tvrtke Hrvatska pošta i telekomunikacije od 1990. pa sve do njezina razdruživanja na dvije zasebne tvrtke: Hrvatska pošta d.d. i Hrvatske telekomunikacije d.d. početkom 1999. godine. Hrvatska je u razvoju javne telefonske mreže znatno zaostajala za razvijenim europskim zemljama, a izbijanje Domovinskoga rata i oružana agresija na Republiku Hrvatsku izložili su ju mogućnosti telekomunikacijske i informacijske blokade. Budući da su se građani Hrvatske opredijelili za tržišnu ekonomiju, politički pluralizam i demokratsko društveno uređenje, u načelu se podrazumijevala i poticala sloboda neposrednoga komuniciranja, a ona je, telekomunikacijski gledano, na razini pojedinca ponajviše bila izražena u dostupnosti domaćih i međunarodnih javnih telefonskih veza. U obrađenom su razdoblju na nacionalnom planu napravljeni ključni infrastrukturni zahvati i uvedena je suvremena tehnologija s novim telekomunikacijskim uslugama, što je omogućilo da Hrvatska prestane biti telekomunikacijski nerazvijena, a na međunarodnom planu postala je prepoznatljiv telekomunikacijski partner te dio tranzitnoga telekomunikacijskog mosta između istočne i zapadne te sjeverne i južne Europe.

Ključne riječi: telefon; telefonija; mobitel; telekomunikacije; Hrvatska pošta i telekomunikacije

\footnotetext{
* Ovaj je rad financirala Hrvatska zaklada za znanost projektom: IP-2016-06-2015 Modernizacija urbanog života u Hrvatskoj kroz prizmu razvoja komunalne infrastrukture u 19. i 20 stoljeću.
} 
Uvod

Početkom 90-ih godina Hrvatska je naglom tranzicijom prešla iz socijalističke u tržišnu ekonomiju, iz jednopartijskoga političkog sustava u demokratsko višestranačje, te je bila izložena teškom višegodišnjem ratu u borbi za opstanak i samostalnost. U tim okolnostima morala se strateški odrediti prema presudno važnoj djelatnosti - telekomunikacijama, koje su istodobno bile generator ekonomskoga razvitka i izvor financijske dobiti, čiji je razvitak bio preduvjet za stvaranje uistinu demokratskoga društva u čijoj podlozi stoji sloboda komuniciranja, te koje su naposljetku bile ključne da bi se u ratnim uvjetima pravovremeno posredovale informacije u zemlji i inozemstvu. Kako bih donekle obrazložio glavne značajke razvoja javne telefonije u Republici Hrvatskoj (RH), koristio sam se arhivskim materijalom tvrtke Hrvatska pošta i telekomunikacije (HPT) iz nacionalnoga poštanskog i telekomunikacijskog muzeja u Zagrebu (HT muzej) i velikim brojem članaka iz časopisa HPT: list Hrvatske pošte i telekomunikacija s obiljem vrijednih informacija, koji je bio svojevrsno glasilo HPT-a, a izlazio je od 1991. do 1999. godine. Na temu HPT-a objavljene su i dvije knjige: HPT telekomunikacije (1990 - 1998) urednika Vladimira Brlića i Vlaste Žurić-Hudek te HPT u Domovinskom ratu: 1991-1995 urednika Zlatka Cišpera i Vladimira Gregurića.

Stanje javne telefonije u Republici Hrvatskoj nakon osnivanja tvrtke Hrvatska pošta i telekomunikacije

Zakon o osnivanju javnog hrvatskog poštanskog i telekomunikacijskog poduzeća stupio je na snagu 10. listopada 1990., nakon čega je Vlada RH dala suglasnost na statut toga poduzeća te je 1. siječnja 1991. upisano u sudski registar, čime je pravno prestalo djelovati trinaest različitih PTT poduzeća na području RH, a njihovu djelatnost preuzela je novoosnovana javna tvrtka pod nazivom Hrvatska pošta i telekomunikacije. ${ }^{1}$ Osnivač tvrtke je Sabor RH, a vlasnik RH. ${ }^{2}$ Sjedište hrvatske nacionalne PTT tvrtke smješteno je u Zagrebu u Ulici Nikole Jurišića 13, u povijesnoj zgradi Poštansko-brzojavne palače. Kako sustav razvitka javne telefonije u Socijalističkoj Federativnoj Republici Jugoslaviji (SFRJ) nije bio utemeljen na tržišnim principima poslovanja, suočavao se različitim problemima koji su se manifestirali u nemogućnosti financiranja izgradnje javne telefonske mreže tako da svi zainteresirani građani koji žele biti telefonski pretplatnici to i postanu. Teret izgradnje lokalnih kapaciteta u telefoniji je, velikim dijelom, često padao na samoga budućega telefonskog

\footnotetext{
VOLARIĆ, „Brzo ali ne brzopleto”, 2; B. V., „HPT - javno poduzeće”, 4.

B. V., „HPT - hrvatska pošta i telekomunikacije”, 1.
} 
pretplatnika, a u mnogim sredinama izgradnju tih kapaciteta organizirale su mjesne zajednice, te su u skladu s manjkavom razvojnom politikom bitni telekomunikacijski kapaciteti građeni na mahove. ${ }^{3}$ Rezultat takva pristupa bio je prosjek od 17,11 telefonskih priključaka na 100 stanovnika u Hrvatskoj 1990., što ju je svrstavalo u skupinu europskih zemalja koje su se nalazile na začelju po razvijenosti javne telefonije. ${ }^{4} \mathrm{Za}$ usporedbu, iste godine Švedska ima 68,33 glavnih telefonskih priključaka, Švicarska 58,76, Austrija 41,80, Njemačka 40,11 , a susjedna Italija 38,76 telefonskih priključaka na 100 stanovnika. ${ }^{5} \mathrm{Na}$ samom početku rada HPT se suočio s nezahvalnom ostavštinom iz vremena SFRJ. U cijeloj Hrvatskoj postojalo je oko 130.000 nerealiziranih telefonskih priključaka koje su ugovorila bivša PTT poduzeća (investicija od oko $300 \mathrm{mi}$ lijuna američkih dolara), a na računima samoga poduzeća bilo je tek 4 milijuna jugoslavenskih dinara. ${ }^{6} \mathrm{Na}$ jednoj od prvih sjednica Upravnoga odbora HPT-a, održanoj 18. prosinca 1990., za postojeće stanje u reguliranju odnosa s budućim pretplatnicima telefonske mreže u RH ustanovljeno je da je „tako loše da gore ne može biti”, zbog čega je donesena troznačna odluka: da se svi budući telefonski pretplatnici u RH u javnu telefonsku mrežu uključuju pod jednakim financijskim uvjetima, da će uvjeti priključivanja biti isti te da će cijena telefonskoga priključka iznositi 2.500 njemačkih maraka. ${ }^{7} \mathrm{Na}$ prvoj novinskoj konferenciji HPT-a, održanoj krajem siječnja 1991., naznačen je početak promjene poslovne paradigme i tržišna orijentacija nove organizacije, pa je jasno naglašeno da se javna telefonska mreža ne može razvijati na temelju novčane participacije građana u cijeni priključka, što je u SFRJ bilo pravilo, ili pak iznimno visokim naknadama privrednim subjektima, nego se sredstva moraju osigurati većom tržišnom cijenom telefonskoga impulsa, koja je u to vrijeme bila nekoliko puta manja nego što je to bilo uobičajeno u svijetu. ${ }^{8}$ Već u veljači 1991. raste cijena telefonskoga impulsa za $25 \%$ uz opravdanje da je nova poslovna politika HPT-a da tržišnom cijenom impulsa pokrije troškove telefonskoga priključka. ${ }^{9} \mathrm{~S}$ druge strane razmišlja se da povećana cijena telefonskoga impulsa, u uvjetima nedostatno razvijenih telefonskih kapaciteta, treba služiti i kao varijabla reguliranja telefonskoga prometa tako da se višom tarifom telefonskoga impulsa u doba najvišega opterećenja sustava odvrati telefonske pretplatnike od korištenja telefona, odnosno da se nižom cijenom

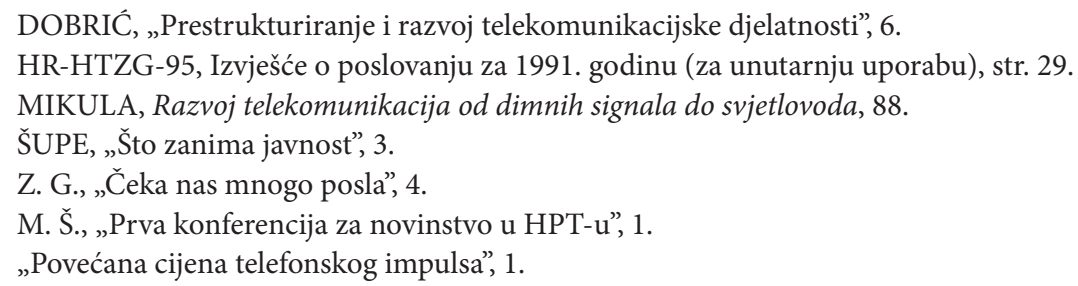


impulsa (tijekom noći) potakne pretplatnike na učestalije korištenje telefonske linije u manje atraktivno vrijeme. ${ }^{10}$

Ionako tešku situaciju u javnoj telefoniji u Hrvatskoj dodatno je opteretilo izbijanje otvorenih ratnih sukoba i početak Domovinskoga rata, tijekom kojega je bilo od životne važnosti održati i unaprijediti javne telekomunikacijske sustave, a posebno telefoniju, iz opravdanoga straha da RH ne završi u telekomunikacijskoj i informacijskoj blokadi. O tome svjedoči i podatak da su tijekom samo nekoliko najžešćih mjeseci ratnih sukoba u Hrvatskoj Ministarstvo obrane i Glavni stožer Hrvatske vojske uputili telefaksom HPT-u više od 20.000 zahtjeva koji su se odnosili na potrebu za osiguranjem nesmetanih komunikacija. ${ }^{11}$ Prva telefonska centrala izbačena iz prometa zbog ratnih sukoba u Hrvatskoj bila je ona na Plitvičkim jezerima u travnju 1991., kapaciteta 500 priključaka. ${ }^{12}$ Tijekom lipnja iste godine na njezinu mjestu trebala je biti instalirana nova automatska telefonska centrala, proizvod Tvornice telekomunikacijskih uređaja „Nikola Tesla” iz Zagreba, međutim pokazalo se da zbog nastavka oružanoga sukoba to neće biti moguće. ${ }^{13} \mathrm{U}$ pojedinim fazama tijekom 1991. u Hrvatskoj se broj telefonskih centrala u prometu smanjio sa 690 na 430, a krajem iste godine izvan prometa bilo je otprilike 193.000 telefonskih priključaka (od toga 93.000 na okupiranom teritoriju $\mathrm{RH}$ ). ${ }^{14}$ Do početka listopada 1991. uništeno je 150 automatskih telefonskih centrala, razoreni su ključni radio-relejni kapaciteti, presječeni glavni koaksijalni kabeli, a štete uzrokovane ratom u HPT-u su se procjenjivale na preko 350.000.000 dolara. ${ }^{15}$ Već sljedeće godine procjena štete narasla je na pola milijarde američkih dolara. ${ }^{16}$ Glavnina štete odrazila se na probleme u međumjesnom telefonskom prometu, a svojevrstan je paradoks da je usprkos tim događajima porastao međunarodni telefonski promet. Naime, unatoč prekidu interkontinentalnih veza sa Sjedinjenim Američkim Državama (SAD), Australijom i Kanadom koje su išle preko zemaljske satelitske postaje Ivanjica (Srbija) te veza sa zemljama koje su bile uspostavljane preko međunarodne telefonske centrale Beograd, a prije svega zahvaljujući razumijevanju inozemnih telekomunikacijskih uprava te $\mathrm{u}$ suradnji s američkom tvrtkom AT\&T upeterostručen je kapacitet kanala zakupljenih u interkontinentalnom podmorskom transatlantskom telekomunikacijskom kabelu TAT-8, čime je osigurano nesmetano odvijanje prometa prema

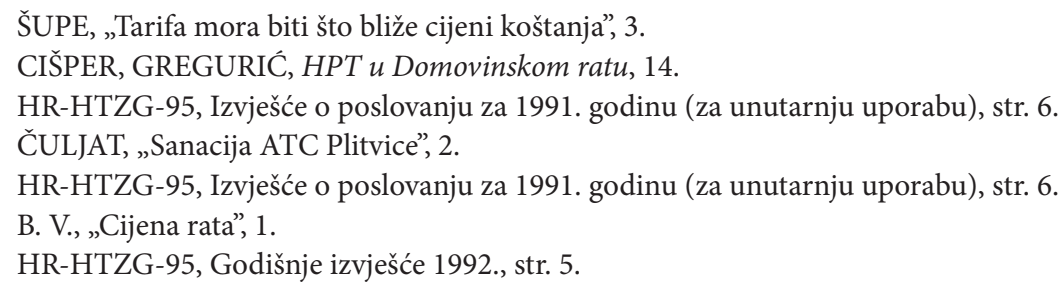


SAD-u, Australiji i Kanadi. ${ }^{17}$ Povezivanje na TAT- 8 omogućeno je izgradnjom digitalnoga radio-relejnoga prijenosnog sustava preko Maribora za Austriju (60 kanala Graz, 60 kanala Beč), što je bilo prvo korištenje digitalnoga prijenosnog sustava izvan granica naše zemlje, a znatno je doprinijelo otklanjanju telekomunikacijske i informacijske blokade Hrvatske. ${ }^{18}$ Time su ostvareni preduvjeti da Austrija omogući daljnje posredovanje telefonskoga prometa, što je u listopadu 1991. dovelo do prvi put premašenih 10 milijuna međunarodnih minuta odlaznih telefonskih poziva, pri čemu su najveću zastupljenost imali pozivi upućeni u Njemačku (43,2 \%), Austriju (11,1 \%), Italiju (10,3 \%), Švicarsku $(6,7 \%)$ i SAD $(4,2 \%) .{ }^{19}$ Ratna zbivanja djelovala su kao poticaj razvoju javne telefonije i potaknula ozbiljnije promišljanje o rekonstrukciji kompletne javne telefonske mreže i njezinoj modernizaciji, uz neizbježno razvijanje nacionalne mobilne telefonske mreže, a sve da bi se postigla njezina robusnost i omogućilo nesmetano funkcioniranje čak i u uvjetima prometne prenapregnutosti ili pak uslijed djelovanja drugih izvanrednih događaja. Za tu svrhu bila bi potrebna izgradnja novih stupnjeva digitalnih komutacija i tranzitnih sustava utemeljenih na svjetlovodnim kabelima da bi došlo do diversifikacije i decentralizacije telekomunikacijske mreže, koja bi istovremeno znatno povećala kapacitet, što bi posljedično dovelo i do izgradnje novih telekomunikacijskih spojeva Hrvatske sa svijetom. ${ }^{20} \mathrm{U}$ međuvremenu je bilo potrebno daljnjim hitnim mjerama obnoviti telefonske veze sa susjednim zemljama, pa je 18. svibnja 1991. puštena u rad analogna radio-relejna veza kapaciteta 300 kanala između Zagreba i Budimpešte, čime se broj mogućih telefonskih veza između dvije prijestolnice povećao na 120, a tom se vezom dijelom odvijao i promet prema drugim zemljama istočne Europe, uključujući Rusiju. ${ }^{21}$

Izgradnja komutacijskih čvorišta, modernih optičkih kabelskih sustava prijenosa i članstvo u međunarodnim organizacijama

Da bi se osigurala moderna tehnologija potrebna za rekonstrukciju telefonske mreže, HPT je u svibnju 1992. održao sastanke s predstavnicima uglednih zapadnoeuropskih proizvođača telekomunikacijske opreme, tvrtkama Ericsson i Siemens, iznoseći im svoje razvojne planove i potrebe na polju javne telefonije. ${ }^{22}$ Reguliranje bilateralnih odnosa s telekomunikacijskim

\footnotetext{
VOLARIĆ, „Preko 10 milijuna međunarodnih minuta”, 11.

ŠUPE, „Prvi digitalni kontakti sa svijetom”, 1.

VOLARIĆ, „Preko 10 milijuna međunarodnih minuta”, 11.

VOLARIĆ, „Telekomunikacijska mreža Republike Hrvatske”, 3.

VOLARIĆ, „Radio-relejna veza Zagreb-Budimpešta”, 2.

M. Š., „Predstavnici tvrtke Ericsson u Zagrebu”, 10; M. Š., „Dogovori o poslovnoj suradnji HPT - Siemens", 10.
} 
upravama pojedinih zemalja, recipročno obračunavanje međunarodnoga telefonskog prometa, kao i planiranje te ekspanzija internacionalnih veza postali su lakši od 3. lipnja 1992., kada Hrvatska postaje članicom Međunarodne telekomunikacijske udruge (International Telecommunications Union - ITU) u Ženevi, specijalizirane agencije Ujedinjenih naroda za telekomunikacije. ${ }^{23}$ Svi ti napori konkretizirali su se i potpisivanjem važnih ugovora s međunarodnim partnerima, pa je sa švedskom tvrtkom Ericsson 20. rujna 1992. potpisan ugovor o isporuci pet najmodernijih telefonskih centrala ukupnoga kapaciteta 60.000 priključaka (model AXE 10) za potrebe međunarodne centrale Zagreb i tranzitno-međunarodnih centrala za Rijeku, Osijek i Split. ${ }^{24}$ Istoga je mjeseca s njemačkim Siemensom potpisan ugovor o nabavi pedeset radio-relejnih digitalnih sustava prijenosa, a krajem listopada u Milanu je potpisan ugovor s talijanskim proizvođačem Alcatel - Telettrom o nabavi telekomunikacijske opreme koja će znatno osnažiti telekomunikacijske prijenosne sustave. ${ }^{25}$ Svrha tih događaja bila je usmjerena pripremi izgradnje telekomunikacijske mreže magistralne važnosti tijekom 1993. i u komutacijama (telefonske centrale) i u prijenosu (razgranata svjetlovodna mreža s digitalnim prijenosnim sustavom), što će osigurati infrastrukturnu podlogu za rast broja telefonskih pretplatnika tijekom 1994. i godina što će uslijediti. Strateški ciljevi HPT-a do 1995. uključivali su povećanje kapaciteta telefonske mreže za $66 \%$ uz posljedični rast broja glavnih telefonskih priključaka na 100 stanovnika, digitalizaciju prijenosnih sustava i lokalnih centrala, građenje podmorskih i kopnenih optičkih međunarodnih sustava prijenosa te razvoj pretplatničkoga potencijala u mobilnoj telefonskoj mreži. ${ }^{26}$ Planska izgradnja telefonskih kapaciteta povoljno se odrazila i na cijenu telefonskoga priključka, koja se gotovo prepolovila, pa je s početnih 2.500 njemačkih maraka već 1993. pala na 1.400 njemačkih maraka, a građanima je omogućeno da plaćaju i svojom starom deviznom štednjom. ${ }^{27}$

Krajem 1992. Hrvatska postaje članica dvaju ključnih globalnih i jednoga europskog sustava satelitskih komunikacija (INMARSAT, INTELSAT, EUTELSAT), što je omogućilo realizaciju telefonske veze uz upotrebu mobilnoga terminala čak i u situacijama kada to nije moguće ostvariti preko zemaljske javne telefonske mreže. Članica INMARSAT-a (Međunarodna organizacija za pomorske satelitske komunikacije) Hrvatska je postala 27. studenog 1992., članica EUTELSAT-a (Europska organizacija za satelitske komunikacije) samo

M. ̌̌., „Međunarodni savez telekomunikacija”, 2.

24 B. V., „U razvoj s najsuvremenijom tehnologijom”, 3; HR-HTZG-95, Godišnje izvješće 1992., str. 5.

25 „Novi digitalni prijenosni sustav”, 3; „Potpisan ugovor s Alcatel - Telettrom”, 3.

26 HR-HTZG-95, Godišnje izvješće 1992., str. 26.

27 GAZIĆ, „Telefoni za staru deviznu štednju”, 6-7. 
nekoliko dana poslije, 3. prosinca 1992., a članica INTELSAT-a (Međunarodna organizacija za telekomunikacijske satelite) 14 . prosinca 1992. godine. ${ }^{28}$ Kao članica ITU-a, Hrvatska je tražila dodjelu vlastitoga međunarodnoga pozivnoga telefonskog broja, a na generalnoj skupštini toga tijela održanoj od 7. do 20 . prosinca u Ženevi razmotrena je mogućnost da se prethodna dvoznamenkasta numeracija za Jugoslaviju (38) pretvori u troznamenkastu, pa bi tako svaka novostvorena država nastala raspadom Jugoslavije dobila svoj broj, a za Hrvatsku je planiran broj $385 .^{29}$ Taj je plan i realiziran, stoga je od ponoći 1. listopada 1993. ITU uveo novi međunarodni pozivni telefonski broj za Hrvatsku 385, za teleks-promet 599 te za prijenos podataka $219 .{ }^{30}$

$S$ obzirom na razvedenost hrvatske morske obale i veliki broj otoka te ratom presječene magistralne prometne i komunikacijske pravce, bilo je potrebno nastaviti razvijati odgovarajuću infrastrukturu kojom će se te otegotne okolnosti ublažiti. Među ostalim, Hrvatska je 10. veljače 1993. u Varšavi pristupila projektu TEL (Trans Europe Line) te se pridružila skupini europskih zemalja (Njemačka, Poljska, Češka, Slovačka, Mađarska, Rumunjska, Hrvatska, Slovenija, Ukrajina, Moldavija, Bjelorusija i Litva) u izgradnji svjetlovodnoga kabelskog sustava prijenosa koji će povezati istočnu i zapadnu Europu, čime je inicijalno preuzela obvezu realizacije optičkoga kabelskog sustava s početnih 8000 govornih kanala na trasi Rijeka - Zagreb - Budimpešta, a naposljetku je projektu pridruženo još nekoliko odsječaka unutar Hrvatske, pa tako i Varaždin - Đakovo - Osijek - Donji Miholjac (granica s Mađarskom) te Zagreb - Bregana (granica sa Slovenijom). ${ }^{31}$ Nadalje, 12. ožujka 1993. u Rijeci je potpisan ugovor o istraživanju jadranskoga podmorja radi polaganja podmorskoga svjetlovodnoga kabela od Rijeke do Dubrovnika, čija će trasa ići dalje prema grčkom otoku Krfu, pa će biti tranzitna telekomunikacijska trasa koja će osnažiti veze srednje Europe sa Sredozemljem. ${ }^{32}$ Za geofizička i seizmička istraživanja jadranskoga podmorja angažiran je Državni hidrografski institut iz Splita, a obavljala su se pomoću posebnoga istraživačkog broda splitskoga Brodospasa koji nosi ime „Junak”. ${ }^{33}$ Daljnje povezivanje s Europom nastavljeno je 13. svibnja u Umagu, gdje je potpisan ugovor između HPT-a i talijanske telekomunikacijske tvrtke IRITEL o izgradnji dvaju podmorskih svjetlovodnih kabelskih sustava koji će povezati Hrvatsku i Italiju, i to na dvije trase: Umag

28 HR-HTZG-96, Izvješće o poslovanju za 1993. godinu (za internu uporabu), str. 9-10; B. S., „Komunikacije preko satelita”, 16.

29 J. V., „Brojevi za Hrvatsku”, 17.

30 „Novi pozivni brojevi u međunarodnom telekomunikacijskom prometu”, 5.

31 HR-HTZG-95, Godišnje izvješće 1992., str. 28; GAZIĆ, „Prvo međunarodno telekomunikacijsko povezivanje Hrvatske putem optičkih kabela", 7.

32 KARTALIJA, „Prvi korak - istraživanje jadranskog podmorja”, 11.

33 D. H., „ADRIA 1 - Adriatic submarine optical cable system”, 2. 
- Chioggia te Dubrovnik - Bari. ${ }^{34}$ Napore u izgradnji tranzitnih optičkih kabelskih sustava prema Europi i unutar Hrvatske pratilo je i otvaranje moderniziranih telefonskih centrala mjesnoga i međunarodnoga značaja.

Prvo modernizirano telefonsko komutacijsko čvorište otvoreno je, u skladu s važnosti, u zagrebačkim Remetama 29. svibnja 1993., gdje predsjednik RH Franjo Tuđman pušta u promet međunarodnu i tranzitnu centralu istodobno sa svjetlovodnim kabelskim sustavom prijenosa između Zagreba i Rijeke kojim se, prvi put u Hrvatskoj, uz prijenos govora obavljao i prijenos slike i podataka. ${ }^{35}$ Iskoraci u izgradnji komutacijskih i tranzitnih dijelova telefonske mreže omogućili su potpisivanje ugovora između Tvornice telekomunikacijskih uređaja „Nikola Tesla” i HPT-a 11. lipnja 1993., kojim je ugovoreno uključenje u promet otprilike 280.000 telefonskih priključaka do kraja godine (od čega na području Telekomunikacijskoga centra Zagreb oko 130.000 priključaka), a koliko je taj pothvat obiman svjedoči i činjenica da su u SFRJ za ostvarenje tolikoga broja priključaka i u mirnodopskom razdoblju bile potrebne tri godine. ${ }^{36}$ Nakon Zagreba u kaskadnom nizu slijede ostali veliki hrvatski gradovi (Split, Rijeka, Osijek (Đakovo/). Dana 1. listopada 1993. otvorena je međunarodno-tranzitna automatska telefonska centrala Split kapaciteta 12.000 međumjesnih telefonskih priključaka te je time znatno unaprijeđena kvaliteta lokalnoga i međunarodnoga telefonskog prometa za čitavo područje južne Hrvatske, a u promet je puštena simboličnim pozivom tadašnjega ministra pomorstva, prometa i veza zagrebačkom gradonačelniku Branku Mikši. ${ }^{37}$ U Rijeci je 26. studenog 1993. puštena u promet međunarodno-tranzitna automatska telefonska centrala Rijeka, koja je jedna od ključnih komutacijskih točaka u izgradnji nacionalne telekomunikacijske mreže, kapaciteta 12.000 međumjesnih i međunarodnih priključaka, s deseterostruko većom mogućnošću prespajanja poziva u odnosu na staru tehnologiju (mogućnost spajanja do 1.800 .000 poziva u jednom satu). ${ }^{38}$ Projekt CIN (Croatia International Networks) zaključen je 21. prosinca 1993. puštanjem u rad međunarodno-tranzitne automatske telefonske centrale u Đakovu. ${ }^{39}$ Tim stupnjem razvoja Hrvatska je osigurala preduvjete za dostizanje europskih standarda gustoće telefonskih priključaka na 100 stanovnika. Od 1991. do 1995. HPT je planirao dosegnuti gustoću od 32 glavna telefonska priključka na 100 stanovnika, a već 1997. potpuno se po-

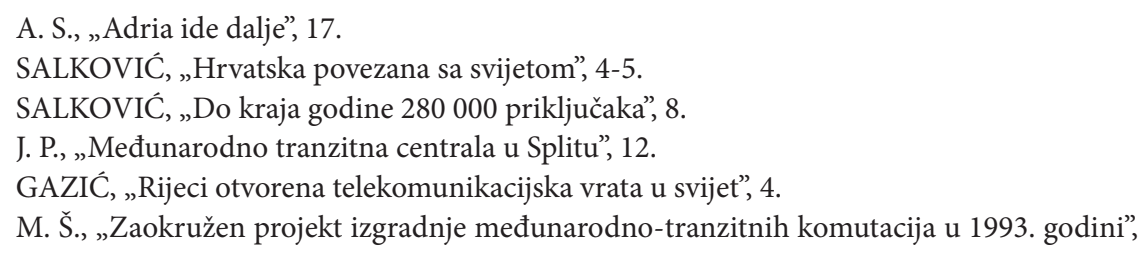


zitivno moglo odgovoriti na zahtjev pretplatnika na uključenje telefonskoga priključka. ${ }^{40}$

Izgradnja novih kapaciteta telefonske mreže kulminirala je organiziranjem akcije popularno nazvane „Zvonko Telefonko”, kojom HPT od početka prosinca 1993. do 31. siječnja 1994. nudi nove uvjete ugovaranja telefonskoga priključka, i fiksnoga i mobilnoga, po cijeni od 999 njemačkih maraka, a riječ je o iznimnom trenutku u razvoju telefonije u Hrvatskoj jer je prvi put izjednačena cijena mobilnoga i fiksnoga telefonskog priključka. ${ }^{41}$ Akcija je okončana u predviđenom roku, a rezultirala je sa 84.827 ugovorenih novih telefonskih pretplatnika diljem Hrvatske u samo dva mjeseca te je Hrvatska u njoj dočekala i svojega milijuntoga telefonskog pretplatnika, umirovljenika Josipa Giacomettija iz Opatije, koji je prigodno nagrađen mobilnim priključkom i mobilnim uređajem Benefon Class. ${ }^{42}$ U Varaždinu je 3. prosinca 1993. obilježeno prvo međunarodno telekomunikacijsko povezivanje Hrvatske s nekom europskom zemljom svjetlovodnim kabelom te je ostvaren prijenos tona i slike s Mađarskom. ${ }^{43} \mathrm{U}$ procesu izgradnje modernih tranzitnih svjetlovodnih sustava Hrvatska je do kraja 1993. (usred rata) uspjela položiti 54.309 km optičkih niti, a 1990. počela je sa samo $156 \mathrm{~km} .{ }^{44}$ Svjetlovodni kabelski sustav koji povezuje jug i sjever Hrvatske, simboličnoga naziva „Jadranko”, kao i lička dionica novoizgrađenoga svjetlovodnoga kabela pušteni su u promet 10. prosinca 1994., pa su prvi put Hrvatsko primorje, otoci Krk, Rab, Pag i Vir te Dalmacija i sjeverna Hrvatska bili povezani najmodernijim telekomunikacijskim sustavom prijenosa, što se povoljno odrazilo na kvalitetu i broj raspoloživih telefonskih veza. ${ }^{45}$ Dionica "Jadranka” između Rijeke i Splita bila je duga $400 \mathrm{~km}$, a omogućila je uspostavljanje 7680 istodobnih telefonskih veza između ta dva hrvatska primorska grada. ${ }^{46}$ U Lovranu je u svibnju 1995. dogovoreno da se u sustav transeuropske telekomunikacijske mreže (TEL) uključe i svjetlovodni kabelski sustav „Jadranko” s oba segmenta (Rijeka - Split, Split - Dubrovnik) te trokraki segment od $182 \mathrm{~km}$ Rijeka - Pazin - Pula - Umag, koji je pušten u promet 22. lipnja 1994. pod nazivom „,istarski telekomunikacijski ipsilon”, a omogućio je da se Istra već krajem 1994. približi standardu telefonije u ra-

\footnotetext{
40 M. Š., „Do telefonskog priključka najkasnije za šest mjeseci”, 10.

41 Isto.

42 M. Š., „Do 31. siječnja 1994. godine 84827 sklopljenih ugovora”, 6; „Milijunti telefonski pretplatnik u Hrvatskoj”, 22.

43 GAZIĆ, „Prvo međunarodno telekomunikacijsko povezivanje Hrvatske putem optičkih kabela", 7.

44 HR-HTZG-96, Godišnje izvješće 1993., str. 15.

45 HR-HTZG-96, Izvješće o poslovanju za 1994. godinu (za internu uporabu), str. 3; J. K., „Svjetlovodnim kabelom iz Rijeke uspostavljena tv veza s Gospićem i Splitom”, 17.

46 Z. V., „Jadranko - telekomunikacijska auto-cesta do Splita”, 18.
} 
zvijenim zemljama i dostigne broj od 45 ugrađenih telefonskih priključaka na 100 stanovnika. ${ }^{47}$

Poslovi na polaganju prvoga svjetlovodnoga telekomunikacijskoga kabela u Jadranskom moru, na relaciji Umag (Hrvatska) - Chioggia (Italija), dovršeni su u svibnju 1994., pa se od toga trenutka za telekomunikacijski promet prema Italiji više nije koristila radio-relejna veza preko Slovenije, a njime se obavljao i tranzit telekomunikacijskoga prometa iz zemalja srednje i istočne Europe prema Mediteranu. ${ }^{48}$ Do kraja iste godine HPT je digitalizirao čak 46 \% komutacijskih sustava, a 85 \% mreže prijenosnih sustava bilo je izgrađeno u digitalnoj tehnologiji. ${ }^{49}$ Ipak, još 1995. javne telefonske mreže najvećih hrvatskih gradova (Zagreba, Splita, Rijeke i Osijeka) bile su po ustroju kombinirane analogno-digitalne, ali je modernizacijom učinjen korak naprijed u rastu broja priključaka - uz pomoć elektroničkih automatskih telefonskih centrala sustava AXE-10. Tako je Zagreb postigao gustoću od 38 glavnih telefonskih priključaka na 100 stanovnika, Osijek 38,5, Rijeka 37, a Split 29 glavnih telefonskih priključaka. ${ }^{50}$ Takav razvoj mreže omogućio je da po završetku vojno-redarstvenih akcija „Bljesak” i „Oluja” u dva tjedna budu u funkciji sva ključna telekomunikacijska čvorišta (Petrinja, Glina, Hrvatska Kostajnica, Drniš), u najvećem dijelu osposobljene krajnje telefonske centrale te da se odmah počne s izgradnjom optičkoga kabelskoga prijenosnog sustava na relaciji od Novske preko Okučana do Nove Gradiške da bi se oslobođena područja što brže integrirala u sada već znatno razvijenu telefonsku mrežu RH. ${ }^{51}$ Godine koje su uslijedile veću su važnost posvetile novoj telekomunikacijskoj tehnici (mobilnoj telefoniji) te se javlja novi fenomen na polju javne telefonije. Ipak, posebno je važno istaknuti da bez kvalitetnih komutacijskih i tranzitnih kapaciteta napredak mobilne telefonije sasvim sigurno ne bi tekao na zadovoljavajući način, kao što je to bilo u drugoj polovini 90 -ih godina.

\section{Prva analogna i prva digitalna mobilna telefonska mreža u Hrvatskoj}

U početku u sjeni fiksne telefonije, u Hrvatskoj je počeo isprva skroman razvoj pokretne telefonije, koja će polagano početi konkurirati klasičnoj telefoniji, a naposljetku će ju, čemu smo danas svjedoci, sasvim potisnuti. Naime,

47 HR-HTZG-96, Izvješće o poslovanju za 1994. godinu (za internu uporabu), str. 3; „TEL ide dalje”, 18; KOMBOL, „Suvremeni telekomunikacijski sustav - poticaj gospodarskog razvoja”, 5.

48 HR-HTZG-96, Izvješće o poslovanju za 1994. godinu (za internu uporabu), str. 12; BUHIN, PRPIĆ, „Položen prvi međunarodni telekomunikacijski optički kabel u Jadranskom moru”, I-IV.

49 HR-HTZG-96, Godišnje izvješće 1994., str. 5.

50 BIJELE, „Do potpune digitalizacije - projekt rekonfiguracije mjesne mreže u Osijeku, Rijeci i Splitu”, 6; BIJELE, „Do potpune digitalizacije”, 5.

51 HR-HTZG-97, Izvješće o poslovanju za 1995. godinu (za internu uporabu), str. 3. 
u listopadu 1990. s eksperimentalnim radom započela je prva javna analogna mobilna radio-telefonska mreža u Hrvatskoj na području Zagreba pod nazivom MOBITEL, a mobilni telefonski uređaji Carryphone NMT $450 \mathrm{~S}$ nabavljeni su od tvrtke C-COM (Velika Britanija). ${ }^{52} \mathrm{~S}$ ugovaranjem priključaka za mobilni uređaj počelo se 11. listopada i u dva tjedna potpisano je 215 ugovora, a korisnici su plaćali 58.100 dinara za priključak te 41.500 dinara za mobilni uređaj, što je preračunato iznosilo oko 14.200 tadašnjih njemačkih maraka. ${ }^{53}$ Komercijalni rad mreže MOBITEL počinje 11. siječnja 1991. godine. ${ }^{54}$ Posve je jasno da si je plaćanje iznimno visoke cijene mobilnoga priključka i aparata u to vrijeme mogla priuštiti malena skupina dobrostojećih građana. Potkraj 1991. bilo je 2019 pretplatnika mobilne telefonske mreže, sljedeće godine taj se broj utrostručio (6320 pretplatnika), a u to vrijeme kapacitet analogne mobilne mreže iznosio je samo 13.000 priključaka. ${ }^{55} \mathrm{U}$ većini zemalja srednje i istočne Europe, izuzev Hrvatske, utemeljene su zasebne tvrtke financirane stranim kapitalom (u pravilu $49 \%$ ), čiji je cilj razvijanje javnih mobilnih telefonskih mreža, ali Hrvatska u usporedbi s njima nije zaostajala u broju pretplatnika javne mobilne telefonske mreže utemeljene na sustavu NMT, pa tako u rujnu 1992. ima 4500 pretplatnika, što je više od Estonije (2730), Čehoslovačke (2550), Slovenije (1470), Latvije (1100), Litve (180), ali manje od susjedne Mađarske, koja je imala već 17.000 pretplatnika mobilne mreže budući da je s radom počela kada je mobilna telefonija u Hrvatskoj bila tek u eksperimentalnoj fazi. ${ }^{56}$

Prva digitalna mobilna telefonska mreža u Hrvatskoj pod komercijalnim nazivom CRONET, utemeljena na međunarodnom GSM standardu, uključena je u eksperimentalni rad 11. kolovoza 1995. simboličnim pozivom prvoga hrvatskog predsjednika dr. Franje Tuđmana. ${ }^{57} \mathrm{~S}$ komercijalnim radom počela je 1. veljače 1996. i možemo kazati da je taj trenutak fundamentalno obilježio fenomen javne telefonije u Hrvatskoj imajući u vidu eksplozivan rast broja korisnika i teritorijalnu pokrivenost uslugom gotovo čitavoga teritorija $\mathrm{RH} .{ }^{58}$ Do kraja 1996. u Hrvatskoj je uključeno 13.086 mobilnih telefonskih pretplatnika na mobilnoj mreži 2. generacije, a mogućnost roaminga ugovorena je s 23 partnera (GSM standard tada je bio prihvaćen u više od 60 zemalja Europe

TUPEK, „Mobitel počinje s pokusnim radom”, 3 .

SALKOVIĆ, „Pretplatnici (do)čekali Mobitel”, 7; FERIĆ, „Prijave za mobitel”, 5.

BRLIĆ, ŽURIĆ-HUDEK, HPT telekomunikacije (1990 - 1998), 14.

HR-HTZG-95, Godišnje izvješće 1992., str. 23.

B. T., „Konferencija u Varšavi”, 7.

HR-HTZG-97, Izvješće o poslovanju za 1995. godinu (za internu uporabu), str. 3; „GSM u Hrvatskoj", 18.

58 POLDRUGAČ, „Cronet - odgovor na zahtjeve suvremenog korisnika”, 6. 
i Azije te u Australiji). ${ }^{59}$ Analogna mreža 1. generacije, koja je bila utemeljena na standardu NMT (Nordic Mobile Telephony) istovremeno je dostigla 51.587 mobilnih telefonskih pretplatnika, pa je bilo planirano proširenje njezinih kapaciteta uvođenjem nove MTX telefonske centrale 1997. godine. ${ }^{60}$ Ipak, ubrzo je postalo jasno da će analogna mobilna telefonija morati prepustiti mjesto digitalnoj, kao tehnološki naprednijoj i financijski rentabilnijoj grani mobilne telefonije, budući da je mreža CRONET nakon nepune dvije godine komercijalnoga rada znatno nadmašila mrežu MOBITEL po broju telefonskih pretplatnika.

Hrvatska je 1999. dočekala s 1.574 .973 nepokretnih telefonskih linija u radu (35,2 telefonska priključka na 100 stanovnika) te 173.700 telefonskih priključaka pokretne mreže u radu ${ }^{61} \mathrm{Za}$ usporedbu, 1990. broj iskorištenih mjesnih telefonskih priključaka iznosio je 823.080, a broj pretplatnika mobilne mreže samo $200 .{ }^{62}$ Što se tiče dinamike telefonskoga prometa, 1990. ukupno je utrošeno 7.328.580.000 telefonskih impulsa, a 1998. godine 14.731.002.000 impulsa, što svjedoči da je javna telefonska mreža Hrvatske u izvanredno kratkom i ratom opterećenom razdoblju znatno unaprijeđena, a to se očituje udvostručenjem telefonskoga prometa. ${ }^{63}$ Ukupan kapacitet pristupnih centrala povećan je na 2.253.646 telefonskih pretplatnika, postavljeno je 13.374 telefonskih govornica diljem Hrvatske, a ukupna duljina položenih optičkih niti iznosi $220.000 \mathrm{~km} .{ }^{64}$ Razdvajanjem HPT-a 1. siječnja 1999. nastale su dvije tvrtke: Hrvatska pošta d.d. i Hrvatske telekomunikacije d.d., a potonja je preuzela telekomunikacijski segment djelatnosti s kompletnom pripadajućom telekomunikacijskom infrastrukturom bivše zajedničke tvrtke i 11.000 zaposlenih (od ukupno 28.000). ${ }^{65}$ Tim su činom bila otvorena vrata privatizaciji strateški i financijski iznimno vrijedna dijela hrvatske nacionalne ekonomije, dotad u državnom vlasništvu.

\footnotetext{
HR-HTZG-98, Godišnje izvješće 1996., str. 19.

Isto.

HR-HTZG-100, Godišnje izvješće 1998., str. 10.

HR-HTZG-95, Izvješće o poslovanju za 1991. godinu (za unutarnju uporabu), str. 80.

HR-HTZG-100, Godišnje izvješće 1998., str. 14; HR-HTZG-95, Izvješće o poslovanju za

1991. godinu (za unutarnju uporabu), str. 22.

64 HR-HTZG-100, Godišnje izvješće 1998., str. 16.

65 HR-HTZG-100, Godišnje izvješće 1999., str. 12.
} 
Tablica 1. Broj fiksnih i mobilnih telefonskih priključaka u Hrvatskoj od 1990. do 1998. godine $e^{66}$

\begin{tabular}{|l|c|c|c|}
\hline Godina & $\begin{array}{c}\text { Broj iskorištenih } \\
\text { telefonskih } \\
\text { priključaka u } \\
\text { Hrvatskoj }\end{array}$ & $\begin{array}{c}\text { Broj NMT mobilnih } \\
\text { telefonskih priključaka } \\
\text { (mobilna mreža 1. } \\
\text { generacije MOBITEL) }\end{array}$ & $\begin{array}{c}\text { Broj GSM mobilnih } \\
\text { telefonskih priključaka } \\
\text { (mobilna mreža 2. } \\
\text { generacije CRONET) }\end{array}$ \\
\hline 1990. & 822.988 & oko 200 & - \\
\hline 1991. & 812.998 & 2019 & - \\
\hline 1992. & 886.847 & 6320 & - \\
\hline 1993. & 967.602 & 11.239 & - \\
\hline 1994. & 1.146 .156 & 21.664 & 13.077 \\
\hline 1995. & 1.254 .444 & 32.948 & 68.265 \\
\hline 1996. & 1.358 .134 & 46.712 & 104.713 \\
\hline 1997. & 1.476 .725 & 52.328 & \\
\hline 1998. & 1.574 .973 & 68.987 & - \\
\hline
\end{tabular}

\section{Zaključak}

Tijekom relativno kratka razdoblja nakon proglašenja samostalnosti $\mathrm{RH}$, u kojem je nacionalna telekomunikacijska tvrtka HPT bila u državnom vlasništvu, te usprkos ratnim razaranjima, javna telefonija u Hrvatskoj doživjela je izvanredne uspjehe. Gotovo je udvostručen broj glavnih telefonskih priključaka, izgrađene su suvremene telefonske centrale, položene tisuće kilometara podmorskih i kopnenih svjetlovodnih kabela, sanirane ratne štete, afirmirana dva sustava mobilne telefonije (analogni i digitalni), a Hrvatska je aktivnim sudjelovanjem u međunarodnim projektima izbjegla telekomunikacijsku blokadu i zaostalost te se uspješno povezala s međunarodnim telekomunikacijskim sustavima. Modernizacija javne telefonske mreže rezultirala je većom cjenovnom dostupnošću telefona i približavanjem Hrvatske europskim standardima u korištenju telefona te su stvoreni dobri temelj za daljnji razvitak na području javne telefonije u Hrvatskoj.

66 HR-HTZG-95, Godišnje izvješće 1992., str. 22-23; HR-HTZG-100, Godišnje izvješće 1998., str. 14-16; HR-HTZG-97, Godišnje izvješće 1995., str. 25; HR-HTZG-96, Godišnje izvješće 1994., str. 18; HR-HTZG-96, Godišnje izvješće 1993., str. 18. 


\section{Arhivi}

HR-HTZG: Hrvatska, Arhiv HT muzeja, Zagreb:

- kutija 95: Poslovno izvješće HPT 1991., 1992.

- kutija 96: Poslovno izvješće HPT 1993., 1994.

- kutija 97: Poslovno izvješće HPT 1995.

- kutija 98: Poslovno izvješće HPT 1996.

- kutija 100: Poslovno izvješće HPT 1998.-2000.

\section{Literatura}

A. S. „Adria ide dalje”. HPT: list Hrvatske pošte i telekomunikacija 3 (1993), br. 6: 17.

B. S. „Komunikacije preko satelita”. HPT: list Hrvatske pošte i telekomunikacija 3 (1993), br. 1: 16.

B. T. „Konferencija u Varšavi”. HPT: list Hrvatske pošte i telekomunikacija 2 (1992), br. 12: 7.

B. V. „Cijena rata”. HPT: list Hrvatske pošte i telekomunikacija 1 (1991), br. 11: 1 .

B. V. „HPT - hrvatska pošta i telekomunikacije”. PTT radnik: list poduzeća PTT Zagreb 26 (1990), br. 10: 1.

B. V. „HPT - javno poduzeće”. PTT radnik: list poduzeća PTT Zagreb 26 (1990), br. 11: 4 .

B. V. „U razvoj s najsuvremenijom tehnologijom”. HPT: list Hrvatske pošte i telekomunikacija 2 (1992), br. 11: 3 .

BIJELE, Miroslav. „Do potpune digitalizacije”. HPT: list Hrvatske pošte i telekomunikacija 5 (1995), br. 2: 4-6.

BIJELE, Miroslav. „Do potpune digitalizacije - projekt rekonfiguracije mjesne mreže u Osijeku, Rijeci i Splitu”. HPT: list Hrvatske pošte i telekomunikacija 5 (1995), br. 3: 4-9.

BRLIĆ, Vladimir; ŽURIĆ-HUDEK, Vlasta, ur. HPT telekomunikacije (1990 - 1998). Zagreb: HPT, 1998.

BUHIN, Boris; PRPIĆ, Goran. „Položen prvi međunarodni telekomunikacijski optički kabel u Jadranskom moru”. HPT: list Hrvatske pošte i telekomunikacija 4 (1994), br. 6: I-IV.

CIŠPER, Zlatko; GREGURIĆ, Vladimir, ur. HPT u Domovinskom ratu: 1991-1995. Zagreb: HT d.d., 1999. 
ČULJAT, Marko. „Sanacija ATC Plitvice”. HPT: list Hrvatske pošte i telekomunikacija 1 (1991), br. 6: 2.

D. H. „ADRIA 1 - Adriatic submarine optical cable system”. HPT: list Hrvatske pošte i telekomunikacija 3 (1993), br. 7: 2.

DOBRIĆ, Vladimir. „Prestrukturiranje i razvoj telekomunikacijske djelatnosti u okviru direkcije telekomunikacija HPT”. HPT: list Hrvatske pošte i telekomunikacija 1 (1991), br. 3: 6-7.

FERIĆ, Biserka. „Prijave za mobitel (Split: prvi radio telefoni u lipnju)”. HPT: list Hrvatske pošte i telekomunikacija 1 (1991), br. 2: 5.

GAZIĆ, Slavko. „Prvo međunarodno telekomunikacijsko povezivanje $\mathrm{Hr}$ vatske putem optičkih kabela”. HPT: list Hrvatske pošte i telekomunikacija 3 (1993), br. 12: 7.

GAZIĆ, Slavko. „Rijeci otvorena telekomunikacijska vrata u svijet”. HPT: list Hrvatske pošte i telekomunikacija 3 (1993), br. 12: 4-5.

GAZIĆ, Slavko. „Telefoni za staru deviznu štednju”. HPT: list Hrvatske pošte i telekomunikacija 3 (1993), br. 5: 6-7.

„GSM u Hrvatskoj”. HPT: list Hrvatske pošte i telekomunikacija 5 (1995), br. 10: 18 .

J. K. „Svjetlovodnim kabelom iz Rijeke uspostavljena tv veza s Gospićem i Splitom”. HPT: list Hrvatske pošte i telekomunikacija 5 (1995), br. 1: 17.

J. P. „Međunarodno tranzitna centrala u Splitu”. HPT: list hrvatske pošte i telekomunikacija 3 (1993), br. 11: 12.

J. V. „Brojevi za Hrvatsku”. HPT: list Hrvatske pošte i telekomunikacija 3 (1993), br. 1: 17.

KARTALIJA, Indira. „Prvi korak - istraživanje jadranskog podmorja”. HPT: list Hrvatske pošte i telekomunikacija 3 (1993), br. 4: 11.

KOMBOL, Vladimir. „Suvremeni telekomunikacijski sustav - poticaj gospodarskog razvoja”. HPT: list Hrvatske pošte i telekomunikacija 4 (1994), br. 7: 4-5.

M. Š. „Do 31. siječnja 1994. godine 84827 sklopljenih ugovora”. HPT: list Hrvatske pošte i telekomunikacija 4 (1994), br. 2: 6.

M. Š. „Do telefonskog priključka najkasnije za šest mjeseci”. HPT: list Hrvatske pošte i telekomunikacija 3 (1993), br. 12: 10.

M. Š. „Dogovori o poslovnoj suradnji HPT - Siemens”. HPT: list Hrvatske pošte i telekomunikacija 2 (1992), br. 6: 10.

M. Š. „Međunarodni savez telekomunikacija”. HPT: list Hrvatske pošte i telekomunikacija 2 (1992), br. 7: 2. 
M. Š. „Predstavnici tvrtke Ericsson u Zagrebu”. HPT: list Hrvatske pošte i telekomunikacija 2 (1992), br. 6: 10.

M. Š. „Prva konferencija za novinstvo u HPT-u”. HPT: list Hrvatske pošte i telekomunikacija 1 (1991), br. 2: 1 .

M. Š. „Zaokružen projekt izgradnje međunarodno-tranzitnih komutacija u 1993. godini”. HPT: list Hrvatske pošte i telekomunikacija 4 (1994), br. 1: 5.

MIKULA, Miroslav. Razvoj telekomunikacija od dimnih signala do svjetlovoda. Zagreb: Školska knjiga, 1994.

„Milijunti telefonski pretplatnik u Hrvatskoj”. HPT: list Hrvatske pošte i telekomunikacija 5 (1995), br. 1: 22.

„Novi digitalni prijenosni sustav”. HPT: list Hrvatske pošte i telekomunikacija 2 (1992), br. 11: 3.

„Novi pozivni brojevi u međunarodnom telekomunikacijskom prometu”. HPT: list Hrvatske pošte i telekomunikacija 3 (1993), br. 9: 5.

POLDRUGAČ, Božidar. „Cronet - odgovor na zahtjeve suvremenog korisnika”. HPT: list Hrvatske pošte i telekomunikacija 6 (1996), br. 2: 6-8.

„Potpisan ugovor s Alcatel - Telettrom”. HPT: list Hrvatske pošte i telekomunikacija 2 (1992), br. 11: 3.

„Povećana cijena telefonskog impulsa”. HPT: list Hrvatske pošte i telekomunikacija 1 (1991), br. 2: 1.

SALKOVIĆ, Andreja. „Do kraja godine 280000 priključaka”. HPT: list Hrvatske pošte i telekomunikacija 3 (1993), br. 7: 8-9.

SALKOVIĆ, Andreja. „Hrvatska povezana sa svijetom”. HPT: list Hrvatske pošte i telekomunikacija 3 (1993), br. 6: 4-7.

SALKOVIĆ, Andreja. „Pretplatnici (do)čekali Mobitel”. PTT radnik: list poduzeća PTT Zagreb 26 (1990), br. 11: 7.

ŠUPE, Milena. „Prvi digitalni kontakti sa svijetom”. HPT: list Hrvatske pošte i telekomunikacija 1 (1991), br. 3: 1.

ŠUPE, Milena. „Što zanima javnost”. HPT: list Hrvatske pošte $i$ telekomunikacija 2 (1992), br. 7: 3.

ŠUPE, Milena. „Tarifa mora biti što bliže cijeni koštanja”. HPT: list Hrvatske pošte i telekomunikacija 1 (1991), br. 3: 3.

„TEL ide dalje”. HPT: list Hrvatske pošte i telekomunikacija 5 (1995), br. 6: 18 .

TUPEK, B. „Mobitel počinje s pokusnim radom”. PTT radnik: list poduzeća PTT Zagreb 26 (1990), br. 10: 3. 
VOLARIĆ, Božena. „Brzo ali ne brzopleto”. HPT: list Hrvatske pošte $i$ telekomunikacija 1 (1991), br. 1: 2-3.

VOLARIĆ, Božena. „Preko 10 milijuna međunarodnih minuta”. HPT: list Hrvatske pošte i telekomunikacija 1 (1991), br. 12: 11.

VOLARIĆ, Božena. „Radio-relejna veza Zagreb-Budimpešta”. HPT: list Hrvatske pošte i telekomunikacija 2 (1992), br. 6: 2.

VOLARIĆ, Božena. „Telekomunikacijska mreža Republike Hrvatske Prioriteti u obnovi i razvoju”. HPT: list Hrvatske pošte i telekomunikacija 2 (1992), br. 3: 3.

Z. G. „Čeka nas mnogo posla”. HPT: list Hrvatske pošte i telekomunikacija 1 (1991), br. 1: 4.

Z. V. „Jadranko - telekomunikacijska auto-cesta do Splita”. HPT: list Hrvatske pošte i telekomunikacija 5 (1995), br. 1: 18. 


\section{SUMMARY}

\section{The Development Characteristics of Public Telephony in Croatia from 1990 to 1998}

After the independence of the Republic of Croatia was declared in 1991, the newly-formed national postal and telecommunications company HPT (Croatian Post and Telecommunications) found itself in an unenviable position. Croatia was in the group of countries at the forefront of telecommunications development in Europe. In 1990, it had only 17 telephone connections per 100 inhabitants. However, in the next eight years it moved closer to the European average, doubling its capacity to 35 telephone lines per 100 inhabitants by 1999. It did so despite the devastation of the Homeland War and the enormous damage suffered by its public telephone network. Croatia managed to negate the telecommunications blockade by finding alternative telecommunication routes, and then set out to build an efficient telephony and transmission system based on the use of fibre-optic cables and modern switching equipment. By the end of 1993, international switching hubs in Zagreb, Split, Rijeka, and Đakovo using AXE 10 technology were built, and the following year cities on the Croatian Adriatic coast were connected with cities in continental Croatia by fibre-optic cable. During this process, Croatia received its one-millionth telephone subscriber. Thanks to its participation in the TEL (Trans Europe Line) project, it became part of the telecommunication bridge between Eastern and Western Europe. In addition to the fixed public telephone network, it simultaneously developed a mobile public telephone network, first an analogue mobile network aptly named MOBITEL in 1991, and then the CRONET digital mobile network in 1996. These steps resulted in a significant increase in telephone traffic and the widespread availability of fixed and mobile telephone connections, which completely revolutionised public telephony in Croatia.

Key words: telephone; telephony; mobile phone; telecommunications; HPT (Croatian Post and Telecommunications) 